\title{
A Study on the Awareness Levels of Vocational Counselors regarding Job Competency
}

\author{
Youn Jae Hee ${ }^{1}$, Beak Song $\mathrm{Yi}^{2}$, Kwon Hoi Lym², Kim Min Kyoung ${ }^{2}$ \\ University of Kyonggi ${ }^{l}$, University of Korea ${ }^{2}$
}

\begin{abstract}
This study revaluates the core competency of both career and vocational counselors through IPA techniques, and has the objective of suggesting a strengthening of job competency measures. For this, a survey was distributed country-wide to 246 vocational counselors, and a gap analysis of a paired t-test and an IPA matrix was implemented. The analysis results revealed a gap of 53 competency and 5 sub-competency groups in priority and performance. Additionally, competency was deduced through area groups of the IPA matrix as: 5 maintenance and 2 low-priority; and the requirement for resource adjustment of the surplus area through the concentration area was not identified.

The implications of this study are: first, in the gap analysis results of competency importance and performance, a contrast between the importance of competency and low performance is visible; and second, in light of this low competency that was revealed (especially in performance), it is necessary to boost the level of performance competency relating to this. Finally, utilizing IPA analysis, the competency areas and sub-categories demanded of vocational counselors were examined. Of the 7 areas initially examined, the following 3 displayed high importance but low performance values: Counseling program development and operation, Job-seeking support ability, and Job and career information management ability In accordance with this, the need of the competency education of the career and vocational counselor's license should be boosted, and assistance should be provided to the setting up of life career development paths.
\end{abstract}

\section{Introduction}

There are 162 prospective occupations presented in the 2040 UN Future Report. The first of these has the official title of a 'transitionist': one connecting or switching job placements in the role of a vocational counselor. Currently in Korea, the vocational counselor takes a central role in deciding one of the many various routes surrounding the process of 'job connection', whilst at the same time possessing a registered national technical qualification. The number of those acquiring the vocational counselor certificate continues to increase due to interest in both the position and tri-yearly exam (Q-net). Alongside this, research continues to be undertaken on the vocational counselor's job and competency [13],[12],[27],[25].

Vocational counselors are currently active in the following fields in Korea: Elementary, Middle, and High School, University, Public Agency Job Center, Employment Center, Women Resources Development Center, Middle-aged Job Center, Private Enterprise, and Free/ Charged Job Placement Agency, etc.. They are in charge of Career, Vocational, and Job Offering/Seeking consultation and job placement etc.. However, although there are differences in job description and necessary competency in connection with affiliated agencies, target counseling, and experience etc.., this is not being suitably reflected. Following this, there is a demand for the comprehension of the competency necessary for a national technical qualification equivalent to "Vocational Counselor 2" in accordance with different types of jobs, and also designs for competency development and educational processes in line with this. Through displays of competency, good business results emerge from agencies affiliated with the vocational counselor. With these results being reflected in the management assessment, through measuring the business evaluation, a connection can finally exist between competency evaluation and this business evaluation.

This study will attempt to analyze the gap of competency demand according to the specific form of vocation (as opposed to individual characteristics). It will take steps towards implementing an analysis of performance level centered on the competency importance recognition of career vocational counselors, and relate to the competency levels demanded of career and vocational counselors needed at schools, employment centers, job centers, and private enterprises etc.. 
The core competency demands of currently active career counselors (career coaches), career advisers of women's new work centers, vocational counselors, employment support for high schools and universities, operators of the 'employment success package', and job transfer support counselors (with more than 3 years vocational counseling experience) are being researched. Through this research, human resources based on the competency of future promising career and vocational counselors can be both secured and managed.

Through this type of competency analysis, the extent and differing values present in the competency level of each job group will be suggested. Secondly: based on the study results, basic data that could form foundations for the design, development, and evaluation standard settings of effective competency development programs (when designing a curriculum) will be utilized.

Study problem 1: does a competency gap appear through the perceived competency importance and current activities of organization members relating to the competency and competency performance levels demanded of vocational counselors?

Study problem 2: is there strategic competency concentrated on the primary development of curriculum design?

\section{Theoretical Background}

\section{1 . Career and Vocation}

The term 'career' refers to one's work and experiences relating to this spanning across an entire lifetime[11],[9], whereas 'vocation' refers to the continuous life activities actualized by social solidarity: the demonstration of improvement in a community according to one's personal performance through free will and the act of supporting a family, and also supporting one's individual livelihood through receiving monetary remuneration (Ministry of Employment and Labor, Employment and Labor Dictionary).

Parsons [24], whilst having arranged the conceptual framework through a career guidance movement, claimed that vocational counseling is the act of optimization through scientific advice relating to self-analysis, vocational analysis, and the gap between the self and vocation. Career counseling is mainly viewed as being divided into employment consultation, vocational counseling, and vocational training counseling implemented by being a youth, university student, or career/ adult- orientated in schools and counseling centers etc.. In this study, persons performing career counseling will be referred to as career and vocational counselors. The career counselors of middle and high schools are mainly run by career admissions counseling teachers or professional counseling teachers, focusing on admission counseling, or in specialized cases such as Meister Schools there are separate employment support staff in place whose role it is to support the careers and vocations of its members. These career admissions counseling teachers or professional counseling teachers are formally certified, so there are notable differences between them and certified vocational counselors or career coaches.

\subsection{Vocational Counselor Certification}

Current vocational counselor certification in Korea is classified as both a level 1 and a level 2 National Technical Qualification, and is overseen by the Human Resources Development Service of Korea. The level 2 vocational counselor examination is conducted three times per year, and consists of a written and practical exam, and the level 1 examination takes place only twice per year. The vocational counselor 2 nd level certification has no limits on age or educational experience, and as a national technical qualification in 2014, 21,381 candidates took the exam, and 11,223 (52.5\%) passed. In the practical exam, 15,152 candidates took the exam, and 4,011 (26.5\%) passed. From 2010 onwards, approximately 3000 4000 vocational counselors have emerged annually.

As this vocational counselor certification applies to the ongoing research and development of the National Competency Standard (NCS), after attaining the certification it can be actively used under a number of different vocational names. According to the National Competency Standard, vocational names are classified in accordance with employee performance levels at the vocational counselor's industrial site: level 2- job manager, employment referral counselor; level 3- career counselor, career advisor, career consultant, vocational counselor; level 4- career coach, employment support counselor, career admission counseling teacher, job transfer support specialist, vocational counseling lecturer, occupational therapist, and vocational counseling supervisor (Human Resources Development Service of Korea, 2013).

\subsection{Competency}

McClelland [20] defined competency as: "the prediction of personal results, or a tangible psychological or active characteristic, whilst claiming that competency, more than intelligence quotient (IQ), was better to predict actual results in the workplace. Following this, Spencer \& Spencer [26] stated that competency is a personal and internal characteristic, the origin of which is effective and superior performance in accordance with workplace standards. Spencer \& Spencer [26] and Dubois [4] in particular developed the establishment of the 
'competency model' based on the deduction of specific competency [8]. Gebelein [5] stated that the competency model is defined as the intelligence, functionality, and attitude of necessary members for the achievement of the goals of that organization. Because the term 'competency' had the persuasiveness of referring to the ability of influencing an organization's results directly, many organizations actively utilize the competency model as a tool for improving the results of members.

\subsubsection{A Study of the Competency Model relating} to Vocational Counselors Overseas. When examining the competency model relating to vocational counselors outside of Korea, the competency model suggested in Canada's NSC (National Steering Committee) is for career development workers, classified as core and specialist competency areas. Core competency is comprised of 4 areas of competency: "specialist activity, interpersonal ability, career development knowledge, understanding of demands, and placement", and specialist competency is divided into the following 6 areas: "evaluation, the promotion of personal and collective learning, career consulting, information and resource management, occupation ability development, and community empowerment", and as for common knowledge and technology, the areas: "job-seeking strategy and collective activity promotion" are suggested (NSC 2001, [12])
In the majority of EU countries, in order to recognize the importance of the employment service and to improve human resources expertise, educational standards are arranged according to the European Qualifications Network (EQF) [12]. The EQF is classified into cognitive competence, functional competence, personal competence, and ethical competence. Additionally, competency is subdivided into the ability units of "social welfare and professional counseling", and these competency ability units are classified into 3 groups which can be observed as being applicable to the "general competency of personal and ethical competence: onhand "customer advice competency, role or service improvement, and inter-organizational cooperation (including the "additional competency: system network") [2]. Within these ability units there are also 6, 6, and 7 categories of lower unit.

The IAEVG (International Competencies for Educational and Vocational Guidance) develops guidelines for international levels, focusing on the necessary intelligence, technology, and attitudes offered to the educational and vocational guidance personnel [6]. It is divided into 10 additional specialized competencies in accordance with the 11 basic necessary core competencies and vocational performance service [28],[27]. Aside from this, the IAEVG carries out research relating to personnel competency in vocational counseling and the employment service industry, whilst suggesting competency models in such countries as Australia, America, Ireland, and Japan [12].

Table 1. Vocational Counseling Occupation Contents

\begin{tabular}{|c|c|c|c|c|}
\hline $\begin{array}{l}\text { A } \\
\text { Vocational } \\
\text { Counseling }\end{array}$ & $\begin{array}{l}\text { B } \\
\text { Career } \\
\text { Counseling }\end{array}$ & $\begin{array}{l}\text { C } \\
\text { Career Information } \\
\text { Management }\end{array}$ & $\begin{array}{l}\text { D } \\
\text { Employment } \\
\text { Insurance } \\
\text { Counseling } \\
\end{array}$ & $\begin{array}{l}\text { E } \\
\text { Career Guidance } \\
\text { Program } \\
\text { Operation } \\
\end{array}$ \\
\hline $\begin{array}{l}\text { A-1 } \\
\text { Job Opening } \\
\text { Counseling }\end{array}$ & $\begin{array}{l}\text { B-1 } \\
\text { Career Choice } \\
\text { Counseling }\end{array}$ & $\begin{array}{l}\text { C-1 } \\
\text { Job Opening/ Seeking } \\
\text { Information } \\
\text { Management }\end{array}$ & $\begin{array}{l}\text { D-1 } \\
\text { Employment } \\
\text { Insurance } \\
\text { Adaptability } \\
\text { Management }\end{array}$ & $\begin{array}{l}\text { E-1 } \\
\text { Career Planning } \\
\text { Program } \\
\text { Operation }\end{array}$ \\
\hline $\begin{array}{l}\text { A-2 } \\
\text { Job } \\
\text { Seeking } \\
\text { Counseling }\end{array}$ & $\begin{array}{l}\text { B-2 } \\
\text { Educational } \\
\text { Training } \\
\text { Counseling } \\
\end{array}$ & $\begin{array}{l}\text { C-2 } \\
\text { Vocation/Business } \\
\text { Information } \\
\text { Management } \\
\end{array}$ & $\begin{array}{l}\text { D-2 } \\
\text { Unemployment } \\
\text { Benefit Counseling }\end{array}$ & $\begin{array}{l}\text { E-2 } \\
\text { Career } \\
\text { Program } \\
\text { Operation } \\
\end{array}$ \\
\hline $\begin{array}{l}\text { A-4 } \\
\text { Pioneering } \\
\text { Job } \\
\text { Openings }\end{array}$ & $\begin{array}{l}\text { B-4 } \\
\text { Career Change } \\
\text { Counseling }\end{array}$ & $\begin{array}{l}\text { C-4 } \\
\text { Employment } \\
\text { Labor } \\
\text { Information } \\
\text { Management }\end{array}$ & $\begin{array}{l}\text { D-4 } \\
\text { Occupation Ability } \\
\text { Development } \\
\text { Operation }\end{array}$ & $\begin{array}{l}\text { E-4 } \\
\text { Vocational } \\
\text { Adaptability } \\
\text { Program } \\
\text { Operation }\end{array}$ \\
\hline $\begin{array}{l}\text { A-5 Holding } \\
\text { Recruitment } \\
\text { Events }\end{array}$ & $\begin{array}{l}\text { B-5 } \\
\text { Career Inventory } \\
\text { Implementation }\end{array}$ & $\begin{array}{l}\text { C-5 } \\
\text { Labor Relations } \\
\text { Regulations Information }\end{array}$ & & $\begin{array}{l}\text { E-5 } \\
\text { Career } \quad \text { C } \\
\text { Program }\end{array}$ \\
\hline
\end{tabular}




\begin{tabular}{|c|c|c|c|}
\hline & & Management & Operation \\
\hline & $\begin{array}{l}\text { B-6 } \\
\text { Career Inventory } \\
\text { Description }\end{array}$ & $\begin{array}{l}\text { C-6 } \\
\text { Career Inventory and } \\
\text { Certification } \\
\text { Information } \\
\text { Management }\end{array}$ & $\begin{array}{l}\text { E-6 } \\
\text { Retirement } \\
\text { Program } \\
\text { Operation }\end{array}$ \\
\hline & & $\begin{array}{l}\text { C-7 } \\
\text { Employment Computer } \\
\text { Network Information } \\
\text { Management }\end{array}$ & $\begin{array}{l}\mathrm{F} \\
\text { Vocational } \\
\text { Counseling } \\
\text { Administration } \\
\end{array}$ \\
\hline & & & $\begin{array}{l}\text { F-1 Document } \\
\text { Writing and } \\
\text { Management }\end{array}$ \\
\hline & & & $\begin{array}{l}\text { F-2 } \\
\text { Meeting and } \\
\text { Seminar } \\
\text { Attendance }\end{array}$ \\
\hline & & & $\begin{array}{lr}\text { F-3 r } & \text { Cooperation } \\
\text { with r Related } \\
\text { Organizations }\end{array}$ \\
\hline
\end{tabular}

(Reference: Kong, J.(2006). Job analysis in field of vocational counseling. Human Resource Development Service of Korea.)

\subsubsection{The Competency of Career and Vocational} Counselors. As interest in the career and vocational counselor occupation has increased, there has been a rise in a wide range of research relating to their competency. In the Korea Research Institute for Vocational Education and Training (1998), 6 types of occupational analysis were undertaken through "job analysis of vocational counselor" in vocational counseling, career counseling, job information management, employment insurance, career program operation, and vocational counseling administration. Henceforth this was slightly modified in the Human Resources Development Service of Korea (2006), and "job analysis in field of vocational counseling" was implemented. From 2002, Korea has been in the process of developing job ability standards in accordance with National Competency Standard (NCS) policy ranging through 24 fields of industry. As of 2015, development has been completed on 797 of 857 vocational sub classifications (comprised of 24 main, 77 middle, and 277 small classifications). With studies on competency deemed to be lacking according to vocational systems, the recognition and perceived importance of domestic competency is expanding. In the NCS, the sub classification 'vocational counseling service' competency is divided into 18 levels of ability.

In the National Competency Standard, vocational ability units of vocational counseling are classified into a total of 18 units, with the elements of ability unit suggested. These 18 ability units are comprised of: vocational psychological testing, vocational counseling, vocational adaptability counseling, vocational transfer support counseling, business startup counseling, vocational retention counseling, retirement counseling, vocational rehabilitation counseling, multicultural vocational counseling, in-depth vocational counseling, communal counseling program operation, cyber vocational counseling, vocational counseling research, vocational counseling opportunities, vocational counseling administration, vocational counseling marketing, and others. Through preceding domestic studies, aforementioned vocational counseling occupations and competency analysis results can be expressed in the following Table 2.

Table 2. Preceding Domestic (Korean) Studies on Vocational Counselor Job Competency Analysis

\begin{tabular}{|c|c|c|c|}
\hline Year & Research Institution & Research Title & $\begin{array}{l}\text { Vocational (Competency) } \\
\text { Contents }\end{array}$ \\
\hline 1998 & $\begin{array}{l}\text { Korea Research Institute for } \\
\text { Vocational Education and Training }\end{array}$ & $\begin{array}{l}\text { Vocational Counselor Career } \\
\text { Analysis }\end{array}$ & $\begin{array}{l}6 \text { Duties, Composed of } 33 \\
\text { Lower Task Elements }\end{array}$ \\
\hline 2006 & $\begin{array}{l}\text { Human Resources Development } \\
\text { Service of Korea }\end{array}$ & $\begin{array}{ll}\text { Vocational Counseling } & \text { Consis } \\
\text { Occupational Career Analysis }\end{array}$ & $\begin{array}{l}6 \text { Work Units, Composed } \\
\text { of } 30 \text { Work Unit Elements }\end{array}$ \\
\hline 2009 & $\begin{array}{l}\text { Hyeong-han Yoon, } \\
\text { University }\end{array}$ & $\begin{array}{l}\text { The Influential Factors and } \\
\text { Specialist } \\
\text { Process of a Development } \\
\text { Counselor }\end{array}$ & $\begin{array}{l}6 \text { Categories, Composed of } \\
25 \text { Lower Categories and } \\
48 \text { Concepts }\end{array}$ \\
\hline
\end{tabular}




\begin{tabular}{|c|c|c|c|}
\hline 2011 & $\begin{array}{l}\text { Gang-ho Kim, Geon-nam Lee, } \\
\text { Korea Employment Information } \\
\text { Service }\end{array}$ & $\begin{array}{lr}\text { Competency } & \text { Index } \\
\text { Development of the Human } \\
\text { Resources } \\
\text { Service }\end{array}$ & $\begin{array}{l}10 \text { Competencies, } \\
\text { Composed of } 56 \text { Activity } \\
\text { Indexes }\end{array}$ \\
\hline 2011 & $\begin{array}{lll}\text { Su-hyang Kim, } & \text { Kwangwoon } \\
\text { University } & \end{array}$ & $\begin{array}{l}\text { A Competency Analysis of } \\
\text { Career and Vocational } \\
\text { Counselors }\end{array}$ & $\begin{array}{l}6 \\
6 \\
\text { Composed of } 49 \text { Lower } \\
\text { Comptencies }\end{array}$ \\
\hline 2013 & $\begin{array}{l}\text { Gyeong-ran Roh, Yun-seon Choi, } \\
\text { (The Korean Society for Human } \\
\text { Resource Development) }\end{array}$ & $\begin{array}{l}\text { Vocational Analysis of Career } \\
\text { Advisers in Women's Job } \\
\text { Centers Using the DACUM } \\
\text { Method }\end{array}$ & $\begin{array}{l}9 \text { Duties, Composed of } 28 \\
\text { Tasks, } 164 \text { Task Elements }\end{array}$ \\
\hline 2013 & $\begin{array}{l}\text { Korea Research Institute for } \\
\text { Vocational Education and Training } \\
\text { Korean Vocational Counseling } \\
\text { Association }\end{array}$ & $\begin{array}{l}\text { National Competency Standard } \\
\text { (NCS) Package }\end{array}$ & $\begin{array}{l}\text { Composed of } 18 \text { Ability } \\
\text { Units }\end{array}$ \\
\hline 2014 & $\begin{array}{l}\text { Hak-ah Kim } \\
\text { (Sookmyung Women's University) }\end{array}$ & $\begin{array}{l}\text { Competency } \text { Analysis of } \\
\text { Vocational Transfer Support } \\
\text { Counselors }\end{array}$ & $\begin{array}{l}3 \text { Competency Groups, } \\
\text { Composed of } 13 \\
\text { Competency Elements, } 55 \\
\text { Competency Indexes }\end{array}$ \\
\hline
\end{tabular}

\section{Methodology}

\subsection{Subjects of the Study}

For this study, which was targeted at career and vocational counselors with level 1 or 2 certification and possessing 1 15 years of working experience, researchers were sampled randomly. A total of 246 career and vocational counselors took part in the study. From the survey answers, it appeared that in sub-dividing them into occupational groups: 62 were Job Seeking - Job Opening, Job Placement Counselors, 57 were Vocational Counselors • 39 were Job Seeking Support Officers (High School and University) 33 were Counselors engaging in Job Seeking Success Packages - 28 were Career Coaches (Elementary, Middle, and High School Career Counseling Overseers), and 27 were Outplacement Support Specialists. Additionally, it appeared that of those taking part, 83 were male $(34 \%)$, and 163 were female $(66 \%)$.

In order to grasp the factors comprising the competency demanded of the vocational counselor's occupation and to gauge the levels of importance and performance relating to competency, research was conducted on 246 vocational counselors all over the country. With the possible differing levels of competency according to the target characteristics of each subject (even with subjects having the same occupation), the occupational form of the counselors was considered according to each specific classification.

3.2.1 Analysis Method. The survey process of this study took place over around 4 months from February to June 2016. In order to consider the occupational forms of counselors, the survey was distributed and collected among the target market of career and vocational counselors performing $(\mathrm{A} \sim \mathrm{F})$ duties. A total of 280 copies were distributed and 246 copies collected before the final analysis took place.

Analysis of the collected material was done through the statistical program SPSS 22.0, and in order to analyze the competency importance and performance of the counselors in question and check if there were meaningful levels of difference in the analysis, a paired t-test was conducted on 53 competency sub divisions in each of the 7 areas.

For the analysis and testing of competency, IPA (Importance - Performance Analysis) was used. Importance - Performance Analysis (IPA) was introduced by Martilla \& James (1977), and has been quoted as a useful method for selecting primary improvements, strategic tasks, and required solutions in the academic fields of business, pedagogy, psychology, and others [7],[3], [8].

In a situation where resources are limited, policies should be primarily focused on the area of utilizing Importance - Performance. In order to deduce the results of each item in this analysis method, the importance of each individual applicable item are evaluated, and firstly, the importance of applicable attributes are measured. Additionally, current performance levels relating to each identical item are measured, and the difference in levels (Gap) between recognition and performance is compared and analyzed.

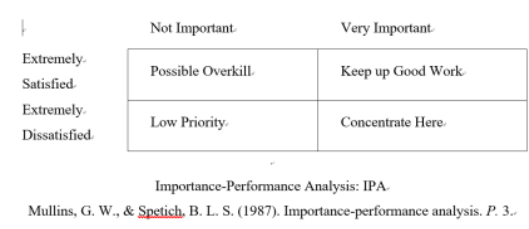


After IPA analyzes, requirement calculated and analyzed by using Borich formula [1]. Borich formula is not just a difference of both each required competence level and present competence level but a process of calculation difference value by summing all of the weighted difference for each case. Borich requirement formula is being utilized in a lot of research.

$\begin{array}{ll}\text { Requirement } & \text { RCL : required } \\ \text { formula }=\frac{\{\Sigma(R C L-P C L)\} * A \cdot R C L}{N} & \text { PCL : present } \\ & \text { competence level } \\ & \text { A.RCL : average of } \\ & \text { required competence } \\ \text { level } & \text { N: total number }\end{array}$

\section{Results}

The averages and standard deviations for each capability group of the importance-performance values for both vocational counselors (and capabilities for each other category) have been collated and analyzed in the table below. The total average for the competency importance analysis results was 4.13 (max. 5.00, min. 1.8), and yielded a standard deviation of 0.817 . Contrastingly, the competency performance analysis results total average was 3.64 (max.5.00, min.1.22), and yielded a standard deviation of 0.850. From these importance-performance analysis results, it can be inferred that despite the competency importance levels shown from vocational counselors, performance levels were comparatively low.

Figure 1. Requirement formula [1]

Table 3. Total Averages for Importance-Performance

\begin{tabular}{l|c|c|}
\hline & Importance & Performance \\
\hline \hline Total Average & 4.13 & 3.64 \\
\hline Maximum Value & 5.00 & 5.00 \\
\hline Minimum Value & 1.8 & 1.22 \\
\hline Standard Deviation & .817 & .850 \\
\hline
\end{tabular}

2. Difference Verification for Competency Importance- Performance

In order to analyze the significant differences in the 7 importance-performance competency groups, the results of the matching sample paired t-test were implemented at a significance level of 0.05 , showing significant differences in all 7 areas (as shown in the table). Additionally, it was also shown that all 53 sub-competencies revealed a significant difference of 0.05 . However, despite the importance level of each sub-competency being high, the performance levels directly observed 'on-site' were revealed to be low. The difference analysis results for each subcompetency is show in the table below.

Table 4. Results Table for each Capability Importance and Capability Performance Area

\begin{tabular}{|c|c|c|c|c|c|c|}
\hline \multirow{2}{*}{ Area } & \multirow{2}{*}{ Competency } & \multicolumn{2}{|c|}{ Importance } & \multicolumn{2}{|c|}{ Performance } & \multirow{2}{*}{ t-value } \\
\hline & & Mean & $S D$ & Mean & $S D$ & \\
\hline IP1 & $\begin{array}{c}\text { Job and career } \\
\text { information management } \\
\text { ability }\end{array}$ & 4.19 & 0.71 & 3.60 & 0.83 & $4.844^{*}$ \\
\hline IP2 & Professionalism & 4.25 & 0.72 & 4.25 & 0.83 & $4.050 *$ \\
\hline IP3 & Counseling skills & 4.37 & 1.06 & 3.88 & 0.72 & $11.821 *$ \\
\hline IP4 & $\begin{array}{c}\text { Positive attitude towards } \\
\text { client }\end{array}$ & 4.34 & 0.70 & 4.05 & 0.72 & $19.771 *$ \\
\hline IP5 & $\begin{array}{c}\text { Counseling program } \\
\text { development and } \\
\text { operation }\end{array}$ & 4.02 & 0.88 & 3.44 & 0.96 & $7.052^{*}$ \\
\hline
\end{tabular}




\begin{tabular}{ccccccc}
\hline IP6 & Professional knowledge & 4.24 & 0.81 & 3.84 & 0.81 & $23.828^{*}$ \\
\hline IP7 & $\begin{array}{c}\text { Job-seeking support } \\
\text { Ability }\end{array}$ & 4.19 & 0.71 & 3.60 & 0.83 & $19.146^{*}$ \\
\hline$* \mathrm{p}<05$ & & & &
\end{tabular}

${ }^{*} \mathrm{p}<.05$

Of the 53 importance and performance competencies, there was the greatest points difference evident in the following 5 areas of job and career information management ability: knowledge related to future social change $(\mathrm{t}=14.251, \mathrm{p}<.05)$, knowledge relating to the type and job information of various careers $(\mathrm{t}=13.493, \mathrm{p}<.05)$, the ability to develop career guidance programs $(t=11.668, \mathrm{p}<.05)$, knowledge relating to psychological theory resulting in an understanding human behavior, personality, stimulus, and motivation etc.. ( $\mathrm{t}=11.302, \mathrm{p}<.05)$, and the ability to communicate effectively according to the characteristics of interviewees $(t=1.932, \mathrm{p}<.05)$. However, there were 5 competencies eliciting a comparatively small points difference between importance and performance: becoming a model career management counselor for each individual interviewee in practical situations $(\mathrm{t}=2.836, \mathrm{p}<.05)$, the ability to realize the central needs of interviewees $(\mathrm{t}=2.836, \mathrm{p}<.05)$, the ability to retain a calm head in coping with various different situations $(\mathrm{t}=5.339, \mathrm{p}<.05)$, the ability to gradually cultivate personal competencies through training or education whilst possessing a level-headed will to learn more $(\mathrm{t}=5.417, \mathrm{p}<.05)$, and retaining an interest and positive curiosity in a variety of areas $(\mathrm{t}=5.418, \mathrm{p}<.05)$.

Table 5. Results Table for each Importance and Performance Sub-competency Area

\begin{tabular}{|c|c|c|c|c|c|}
\hline \multirow{2}{*}{ Sub- competency } & \multicolumn{2}{|c|}{ Importance } & \multicolumn{2}{|c|}{ Performance } & \multirow{2}{*}{$\begin{array}{l}\text { Importance- } \\
\text { Performance } \\
\text { t-value }\end{array}$} \\
\hline & Average & $\begin{array}{l}\text { Standard } \\
\text { Deviation }\end{array}$ & Average & $\begin{array}{l}\text { Standard } \\
\text { Deviation }\end{array}$ & \\
\hline $\begin{array}{l}\text { Knowledge related } \\
\text { to future social } \\
\text { change }\end{array}$ & 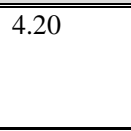 & 0.73 & 3.25 & 0.81 & 14.251* \\
\hline $\begin{array}{l}\text { Knowledge relating } \\
\text { to the type and job } \\
\text { information of } \\
\text { various careers }\end{array}$ & 4.39 & 0.78 & 3.59 & 0.79 & $12.493^{*}$ \\
\hline $\begin{array}{l}\text { Understanding of life } \\
\text { organization }\end{array}$ & 4.12 & 0.55 & 3.73 & 0.79 & $7.189 *$ \\
\hline $\begin{array}{l}\text { Understanding of the } \\
\text { current state of } \\
\text { business }\end{array}$ & 3.93 & 0.76 & 3.34 & 0.90 & $9.172^{*}$ \\
\hline $\begin{array}{l}\text { Knowledge relating } \\
\text { to the business } \\
\text { recruitment process } \\
\text { and personnel } \\
\text { system }\end{array}$ & 4.29 & 0.81 & 3.53 & 0.85 & $10.927 *$ \\
\hline $\begin{array}{l}\text { Information about } \\
\text { different high } \\
\text { school/ university } \\
\text { characteristics and } \\
\text { majors }\end{array}$ & 4.00 & 0.96 & 3.35 & 1.01 & $9.546^{*}$ \\
\hline $\begin{array}{l}\text { Ability to search for } \\
\text { job information }\end{array}$ & 4.50 & 0.66 & 4.11 & 0.77 & $7.278^{*}$ \\
\hline $\begin{array}{l}\text { Ability to analyze } \\
\text { information and } \\
\text { organize data }\end{array}$ & 4.06 & 0.68 & 3.60 & 0.84 & $7.873^{*}$ \\
\hline $\begin{array}{l}\text { Ability to match and } \\
\text { utilize job seeking } \\
\text { information etc.. }\end{array}$ & 4.53 & 0.58 & 4.04 & 0.79 & $8.727 *$ \\
\hline
\end{tabular}




\begin{tabular}{|c|c|c|c|c|c|}
\hline $\begin{array}{l}\text { Ability to search for } \\
\text { information about } \\
\text { education, training, } \\
\text { and certification } \\
\text { relating to job } \\
\text { abilities }\end{array}$ & 4.33 & 0.63 & 3.81 & 0.75 & $8.581^{*}$ \\
\hline $\begin{array}{l}\text { Knowledge relating } \\
\text { to the competencies } \\
\text { of jobs and duties }\end{array}$ & 4.44 & 0.64 & 3.98 & 0.71 & $8.246^{*}$ \\
\hline $\begin{array}{l}\text { Understanding of } \\
\text { inter-connected jobs }\end{array}$ & 4.16 & 0.67 & 3.61 & 0.75 & $10.324^{*}$ \\
\hline $\begin{array}{l}\text { Knowledge enabling } \\
\text { an understanding of } \\
\text { general market flow: } \\
\text { economic trends, } \\
\text { industry change, etc.. }\end{array}$ & 3.86 & 0.79 & 3.35 & 0.87 & $8.208^{*}$ \\
\hline $\begin{array}{l}\text { Ability to understand } \\
\text { and retain } \\
\text { information about } \\
\text { the labor market and } \\
\text { employment trends }\end{array}$ & 4.12 & 0.70 & 3.44 & 0.92 & $10.906^{*}$ \\
\hline $\begin{array}{l}\text { Ability to analyze } \\
\text { and search for } \\
\text { information enabling } \\
\text { an understanding of } \\
\text { industry change and } \\
\text { trends }\end{array}$ & 3.87 & 0.77 & 3.26 & 0.87 & $10.091 *$ \\
\hline $\begin{array}{l}\text { Retaining an interest } \\
\text { and positive } \\
\text { curiosity in a variety } \\
\text { of areas }\end{array}$ & 3.93 & 0.80 & 3.60 & 0.92 & $5.418^{*}$ \\
\hline $\begin{array}{l}\text { Ability to gradually } \\
\text { cultivate personal } \\
\text { capabilities through } \\
\text { training or education } \\
\text { whilst possessing a } \\
\text { level-headed will to } \\
\text { learn more }\end{array}$ & 4.34 & 0.62 & 3.98 & 0.86 & $5.417^{*}$ \\
\hline $\begin{array}{l}\text { Career values of } \\
\text { dedication and } \\
\text { service, extending to } \\
\text { altruism and } \\
\text { consideration etc.. }\end{array}$ & 4.15 & 0.81 & 3.88 & 0.94 & $4.483^{*}$ \\
\hline $\begin{array}{l}\text { Attitude willing to } \\
\text { provide practical } \\
\text { help to interviewees }\end{array}$ & 4.44 & 0.68 & 4.26 & 0.74 & $8.081^{*}$ \\
\hline $\begin{array}{l}\text { Confidence and } \\
\text { belief in self- } \\
\text { competency }\end{array}$ & 4.32 & 0.69 & 3.89 & 0.76 & 9.731* \\
\hline $\begin{array}{l}\text { Self-respect and a } \\
\text { sense of vocation in } \\
\text { one's profession }\end{array}$ & 4.36 & 0.72 & 3.83 & 0.85 & $7.826^{*}$ \\
\hline $\begin{array}{l}\text { Active and } \\
\text { passionate attitude }\end{array}$ & 4.34 & 0.70 & 3.96 & 0.75 & $7.730^{*}$ \\
\hline $\begin{array}{l}\text { Becoming a model } \\
\text { career management } \\
\text { counselor for each } \\
\text { individual }\end{array}$ & 4.17 & 0.72 & 3.76 & 0.82 & $2.836^{*}$ \\
\hline
\end{tabular}




\begin{tabular}{|c|c|c|c|c|c|}
\hline $\begin{array}{l}\text { interviewee in } \\
\text { practical situations }\end{array}$ & & & & & \\
\hline $\begin{array}{l}\text { Ability to understand } \\
\text { an interviewee's } \\
\text { source problems } \\
\text { (central needs) }\end{array}$ & 4.72 & 4.63 & 3.88 & 0.72 & $2.836^{*}$ \\
\hline $\begin{array}{l}\text { Sense of leadership } \\
\text { able to gain the trust } \\
\text { of the interviewee } \\
\text { and provide } \\
\text { appropriate advice }\end{array}$ & 4.39 & 0.67 & 3.97 & 0.72 & $9.681^{*}$ \\
\hline $\begin{array}{l}\text { Affinity to establish } \\
\text { a connection with } \\
\text { somebody upon first } \\
\text { meeting (building } \\
\text { rapport) }\end{array}$ & 4.40 & 0.66 & 4.05 & 0.72 & $7.123^{*}$ \\
\hline $\begin{array}{l}\text { Ability to } \\
\text { communicate } \\
\text { effectively according } \\
\text { to the characteristics } \\
\text { of interviewees }\end{array}$ & 4.54 & 0.62 & 4.07 & 0.70 & $10.932 *$ \\
\hline $\begin{array}{l}\text { Ability to } \\
\text { concentrate and } \\
\text { listen to interviewees }\end{array}$ & 4.53 & 0.60 & 4.12 & 0.75 & $8.439^{*}$ \\
\hline $\begin{array}{l}\text { Ability to utilize } \\
\text { counseling strategy } \\
\text { in terms of } \\
\text { clarification, } \\
\text { reflection, giving } \\
\text { compliments, and } \\
\text { personal advice etc.. }\end{array}$ & 4.20 & 0.68 & 3.70 & 0.75 & $10.421^{*}$ \\
\hline $\begin{array}{l}\text { All-round } \\
\text { knowledge relating } \\
\text { to interviewee } \\
\text { characteristics (e.g. } \\
\text { youth, adolescent, } \\
\text { middle aged, elderly) }\end{array}$ & 4.14 & 0.75 & 3.60 & 0.78 & $10.964 *$ \\
\hline $\begin{array}{l}\text { Ability to analyze } \\
\text { interviewee } \\
\text { competencies and } \\
\text { understand career } \\
\text { problems (elements } \\
\text { obstructing job- } \\
\text { seeking) }\end{array}$ & 4.25 & 0.63 & 3.78 & 0.69 & $10.044 *$ \\
\hline $\begin{array}{l}\text { Ability to effectively } \\
\text { convey analyzed } \\
\text { information and } \\
\text { psychological } \\
\text { evaluations etc.. to } \\
\text { interviewee }\end{array}$ & 4.24 & 0.68 & 3.73 & 0.72 & $10.156^{*}$ \\
\hline $\begin{array}{l}\text { Ability to motivate and } \\
\text { direct interviewee in a } \\
\text { self-regulating and } \\
\text { dominant fashion }\end{array}$ & 4.30 & 0.66 & 3.85 & 0.69 & $8.735^{*}$ \\
\hline $\begin{array}{l}\text { Ethical ability to } \\
\text { keep interviewee }\end{array}$ & 4.55 & 0.67 & 4.24 & 0.63 & $7.327 *$ \\
\hline
\end{tabular}




\begin{tabular}{|c|c|c|c|c|c|}
\hline $\begin{array}{l}\text { information and } \\
\text { trusted matters etc.. } \\
\text { confidential as a } \\
\text { counselor }\end{array}$ & & & & & \\
\hline $\begin{array}{l}\text { Sense of affection } \\
\text { for the interviewee } \\
\text { and general respect } \\
\text { for people }\end{array}$ & 4.43 & 0.73 & 4.15 & 0.76 & 6.894* \\
\hline $\begin{array}{l}\text { Ability to } \\
\text { accommodate and } \\
\text { adequately } \\
\text { sympathize with/ } \\
\text { accept interviewee } \\
\text { without criticism }\end{array}$ & 4.34 & 0.73 & 3.98 & 0.71 & $8.461 *$ \\
\hline $\begin{array}{l}\text { Flexibility to calmly } \\
\text { cope with } \\
\text { interviewee whilst } \\
\text { retaining an unbiased } \\
\text { and open attitude }\end{array}$ & 4.24 & 0.70 & 3.98 & 0.73 & $6.458 *$ \\
\hline $\begin{array}{l}\text { Sense of } \\
\text { responsibility and } \\
\text { honesty enabling } \\
\text { continual } \\
\text { transformation of } \\
\text { interviewee }\end{array}$ & 4.28 & 0.66 & 4.03 & 0.76 & $5.792 *$ \\
\hline $\begin{array}{l}\text { Ability to retain a } \\
\text { calm head in coping } \\
\text { with various } \\
\text { different situations }\end{array}$ & 4.22 & 0.71 & 3.96 & 0.73 & $5.339 *$ \\
\hline $\begin{array}{l}\text { Sympathizing } \\
\text { attitude enabling } \\
\text { support and belief in } \\
\text { interviewee }\end{array}$ & 4.31 & 0.72 & 4.03 & 0.72 & $6.020 *$ \\
\hline $\begin{array}{l}\begin{array}{l}\text { Ability to operate } \\
\text { existing } \\
\text { counseling programs }\end{array} \\
\text { (CAP/ CDP, etc..) }\end{array}$ & 3.98 & 0.89 & 3.24 & 1.10 & $10.744 *$ \\
\hline $\begin{array}{lr}\begin{array}{l}\text { Ability to } \\
\text { career } \\
\text { programs }\end{array} & \begin{array}{l}\text { guidancelop } \\
\text { guidance }\end{array} \\
\end{array}$ & 3.76 & 1.02 & 2.90 & 1.07 & $11.668 *$ \\
\hline $\begin{array}{lr}\text { Ability } & \text { to } \\
\text { persuasively } & \text { lecture } \\
\text { in a } \quad \text { manner } \\
\text { appropriate } & \text { to } \\
\text { interviewee's } & \\
\text { characteristics } & \\
\end{array}$ & 4.01 & 0.97 & 3.36 & 1.05 & $8.996 *$ \\
\hline $\begin{array}{l}\text { Ability to interpret } \\
\text { and implement } \\
\text { psychological } \\
\text { evaluations relating } \\
\text { to career counseling }\end{array}$ & 4.13 & 0.85 & 3.55 & 0.87 & $8.962 *$ \\
\hline $\begin{array}{l}\text { Ability to amend } \\
\text { documents relating } \\
\text { to job applications } \\
\text { and interviews }\end{array}$ & 4.32 & 0.73 & 3.95 & 0.79 & $6.706^{*}$ \\
\hline $\begin{array}{l}\text { Ability to utilize } \\
\text { computers equipped } \\
\text { with }\end{array}$ & 3.94 & 0.84 & 3.60 & 0.89 & 5.799* \\
\hline
\end{tabular}




\begin{tabular}{|c|c|c|c|c|c|c|}
\hline $\begin{array}{l}\text { materials } \quad \text { (PPT, } \\
\text { Video } \\
\text { etc..) }\end{array}$ & & & & & & \\
\hline $\begin{array}{l}\text { Knowledge of theory } \\
\text { currently utilized in } \\
\text { the counseling field }\end{array}$ & 3.83 & 0.77 & 3.38 & 0.75 & & $-2.441^{*}$ \\
\hline $\begin{array}{l}\text { Knowledge relating } \\
\text { to psychological } \\
\text { theory for the } \\
\text { understanding of } \\
\text { human behavior, } \\
\text { personality, } \\
\text { stimulus, and } \\
\text { motivation etc.. }\end{array}$ & 3.84 & 0.75 & 3.32 & 0.81 & & $11.302 *$ \\
\hline $\begin{array}{l}\text { Knowledge relating } \\
\text { to the developmental } \\
\text { theories of vocation } \\
\text { and counseling }\end{array}$ & 3.74 & 0.79 & 3.26 & 0.78 & & 9.196* \\
\hline $\begin{array}{l}\text { Ability to discover } \\
\text { job-seeking } \\
\text { companies }\end{array}$ & 4.26 & 0.87 & 3.74 & 1.01 & & $9.211^{*}$ \\
\hline $\begin{array}{l}\text { Ability to find } \\
\text { employment for job } \\
\text { seekers }\end{array}$ & 4.45 & 0.71 & 4.04 & 0.78 & & $9.331^{*}$ \\
\hline $\begin{array}{l}\text { Ability to operate } \\
\text { and plan events } \\
\text { relating to the fields } \\
\text { of 'career' and } \\
\text { 'vocation' }\end{array}$ & 3.85 & 0.86 & 3.34 & 1.02 & & 7.917* \\
\hline $\begin{array}{l}\text { Ability to offer adapti } \\
\text { employment }\end{array}$ & support after & 3.77 & $\begin{array}{l}3.2 \\
7\end{array}$ & 0.88 & $8.609 *$ & \\
\hline
\end{tabular}

Average values were used to analyze areas showing the gap between importance and performance in the 7 competency groups, and the position of each competency group in the IPA matrix is expressed in Figure 2. According to the IPA matrix of the 7 competency areas, all high importance and performance values were related to the "Keep up (the) good work" comments. The relative positions of the average importance and performance values are expressed below in Figure 2.

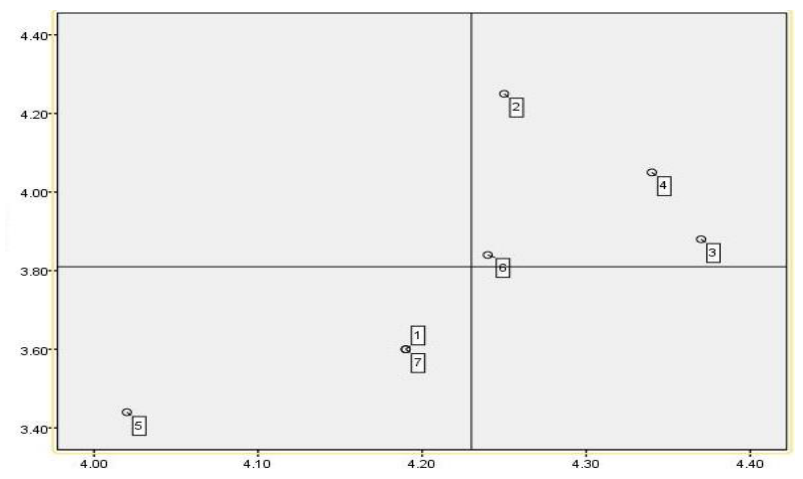

Figure 2. Each competency group in the IPA matrix

Competencies primarily in need of improvement were found in the following 3 high importance but low performance areas: Counseling program development and operation, Job-seeking support ability, and Job and career information management ability. Meanwhile, according to a Borich formula, competency priorities are appointed a by each competency. Of the 53 importance and performance 
competencies, there was the following 5 displayed high requirements: Knowledge relating to the type and job information of various careers, Knowledge related to future social change, Knowledge relating to the business recruitment process and personnel system, Understanding of life organization, Ability to search for job information. On the other hand, it was confirmed the following 5 displayed low requirements: Knowledge relating to the type and job information of various careers Ability to offer adaptive support after employment, Ability to operate and plan events relating to the fields of 'career' and 'vocation', Ability to find employment for job seekers, Ability to find employment for job seekers, Ability to discover job-seeking companies, Knowledge relating to the developmental theories of vocation and counseling.

Table 6. Results Table for each Importance and Performance Sub-competency Area

\begin{tabular}{|c|c|c|c|c|c|}
\hline \multirow{2}{*}{ Sub- competency } & \multicolumn{2}{|c|}{ Importance } & \multicolumn{2}{|c|}{ Performance } & \multirow{2}{*}{$\begin{array}{c}\text { Importance- } \\
\text { Performance } \\
\begin{array}{c}\text { Requiremen } \\
\text { (rank) }\end{array}\end{array}$} \\
\hline & Average & $\begin{array}{l}\text { Standard } \\
\text { Deviation }\end{array}$ & Average & $\begin{array}{l}\text { Standard } \\
\text { Deviation }\end{array}$ & \\
\hline $\begin{array}{l}\text { Knowledge relating to the } \\
\text { type and job information of } \\
\text { various careers }\end{array}$ & 4.39 & 0.78 & 3.59 & 0.79 & $2.11(1)$ \\
\hline $\begin{array}{l}\text { Knowledge related to future } \\
\text { social change }\end{array}$ & 4.2 & 0.73 & 3.25 & 0.81 & $2.10(2)$ \\
\hline $\begin{array}{l}\text { Knowledge relating to the } \\
\text { business recruitment process } \\
\text { and personnel system }\end{array}$ & 4.29 & 0.81 & 3.53 & 0.85 & $1.91(3)$ \\
\hline $\begin{array}{l}\text { Understanding of life } \\
\text { organization }\end{array}$ & 4.12 & 0.55 & 3.73 & 0.79 & $1.88(4)$ \\
\hline $\begin{array}{l}\text { Ability to search for job } \\
\text { information }\end{array}$ & 4.5 & 0.66 & 4.11 & 0.77 & $1.85(5)$ \\
\hline $\begin{array}{l}\text { Ability to match and utilize } \\
\text { job seeking information etc.. }\end{array}$ & 4.53 & 0.58 & 4.04 & 0.79 & $1.80(6)$ \\
\hline $\begin{array}{l}\text { Understanding of the current } \\
\text { state of business }\end{array}$ & 3.93 & 0.76 & 3.34 & 0.9 & $1.78(7)$ \\
\hline $\begin{array}{l}\text { Information about different } \\
\text { high school/ university } \\
\text { characteristics and majors }\end{array}$ & 4 & 0.96 & 3.35 & 1.01 & $1.72(8)$ \\
\hline $\begin{array}{l}\text { Ability to search for } \\
\text { information about education, } \\
\text { training, and certification } \\
\text { relating to job abilities }\end{array}$ & 4.33 & 0.63 & 3.81 & 0.75 & $1.69(9)$ \\
\hline $\begin{array}{l}\text { Knowledge relating to the } \\
\text { competencies of jobs and } \\
\text { duties }\end{array}$ & 4.44 & 0.64 & 3.98 & 0.71 & $1.68(10)$ \\
\hline $\begin{array}{l}\text { Ability to analyze } \\
\text { information and organize } \\
\text { data }\end{array}$ & 4.06 & 0.68 & 3.6 & 0.84 & $1.65(11)$ \\
\hline $\begin{array}{l}\text { Understanding of inter- } \\
\text { connected jobs }\end{array}$ & 4.16 & 0.67 & 3.61 & 0.75 & $1.54(12)$ \\
\hline $\begin{array}{l}\text { Ability to understand and } \\
\text { retain information about the } \\
\text { labor market and } \\
\text { employment trends }\end{array}$ & 4.12 & 0.7 & 3.44 & 0.92 & $1.46(13)$ \\
\hline $\begin{array}{l}\text { Knowledge enabling an } \\
\text { understanding of general } \\
\text { market flow: economic } \\
\text { trends, industry change, etc.. }\end{array}$ & 3.86 & 0.79 & 3.35 & 0.87 & $1.39(14)$ \\
\hline
\end{tabular}




\begin{tabular}{|c|c|c|c|c|c|}
\hline $\begin{array}{l}\text { Ability to gradually cultivate } \\
\text { personal capabilities through } \\
\text { training or education whilst } \\
\text { possessing a level-headed } \\
\text { will to learn more }\end{array}$ & 4.34 & 0.62 & 3.98 & 0.86 & $1.38(15)$ \\
\hline $\begin{array}{l}\text { Attitude willing to provide } \\
\text { practical help to } \\
\text { interviewees }\end{array}$ & 4.44 & 0.68 & 4.26 & 0.74 & $1.34(16)$ \\
\hline $\begin{array}{l}\text { Ability to analyze and } \\
\text { search for information } \\
\text { enabling an understanding } \\
\text { of industry change and } \\
\text { trends }\end{array}$ & 3.87 & 0.77 & 3.26 & 0.87 & $1.31(17)$ \\
\hline $\begin{array}{l}\text { Ability to understand an } \\
\text { interviewee's source } \\
\text { problems (central needs) }\end{array}$ & 4.72 & 4.63 & 3.88 & 0.72 & $1.31(18)$ \\
\hline $\begin{array}{l}\text { Confidence and belief in } \\
\text { self- competency }\end{array}$ & 4.32 & 0.69 & 3.89 & 0.76 & 1.31 (19) \\
\hline $\begin{array}{l}\text { Self-respect and a sense of } \\
\text { vocation in one's profession }\end{array}$ & 4.36 & 0.72 & 3.83 & 0.85 & $1.29(20)$ \\
\hline $\begin{array}{l}\text { Career values of dedication } \\
\text { and service, extending to } \\
\text { altruism and consideration } \\
\text { etc.. }\end{array}$ & 4.15 & 0.81 & 3.88 & 0.94 & $1.28(21)$ \\
\hline $\begin{array}{l}\text { Retaining an interest and } \\
\text { positive curiosity in a } \\
\text { variety of areas }\end{array}$ & 3.93 & 0.8 & 3.6 & 0.92 & $1.27(22)$ \\
\hline $\begin{array}{l}\text { Active and passionate } \\
\text { attitude }\end{array}$ & 4.34 & 0.7 & 3.96 & 0.75 & $1.23(23)$ \\
\hline $\begin{array}{l}\text { Becoming a model career } \\
\text { management counselor for } \\
\text { each individual interviewee } \\
\text { in practical situations }\end{array}$ & 4.17 & 0.72 & 3.76 & 0.82 & $1.16(24)$ \\
\hline $\begin{array}{l}\text { Sense of leadership able to } \\
\text { gain the trust of the } \\
\text { interviewee and provide } \\
\text { appropriate advice }\end{array}$ & 4.39 & 0.67 & 3.97 & 0.72 & $1.12(25)$ \\
\hline $\begin{array}{l}\text { Ability to communicate } \\
\text { effectively according to the } \\
\text { characteristics of } \\
\text { interviewees }\end{array}$ & 4.54 & 0.62 & 4.07 & 0.7 & $1.09(26)$ \\
\hline $\begin{array}{l}\text { Affinity to establish a } \\
\text { connection with somebody } \\
\text { upon first meeting (building } \\
\text { rapport) }\end{array}$ & 4.4 & 0.66 & 4.05 & 0.72 & $1.08(27)$ \\
\hline $\begin{array}{l}\text { Ability to concentrate and } \\
\text { listen to interviewees }\end{array}$ & 4.53 & 0.6 & 4.12 & 0.75 & $1.04(28)$ \\
\hline $\begin{array}{l}\text { Ability to utilize counseling } \\
\text { strategy in terms of } \\
\text { clarification, reflection, } \\
\text { giving compliments, and } \\
\text { personal advice etc.. } \\
\end{array}$ & 4.2 & 0.68 & 3.7 & 0.75 & $0.94(29)$ \\
\hline $\begin{array}{l}\text { All-round knowledge } \\
\text { relating to interviewee } \\
\text { characteristics (e.g. youth, } \\
\text { adolescent, middle aged, } \\
\text { elderly) }\end{array}$ & 4.14 & 0.75 & 3.6 & 0.78 & $0.89(30)$ \\
\hline
\end{tabular}




\begin{tabular}{|c|c|c|c|c|c|}
\hline $\begin{array}{l}\text { Ability to analyze } \\
\text { interviewee competencies } \\
\text { and understand career } \\
\text { problems (elements } \\
\text { obstructing job-seeking) }\end{array}$ & 4.25 & 0.63 & 3.78 & 0.69 & $0.87(31)$ \\
\hline $\begin{array}{l}\text { Ability to effectively convey } \\
\text { analyzed information and } \\
\text { psychological evaluations } \\
\text { etc.. to interviewee }\end{array}$ & 4.24 & 0.68 & 3.73 & 0.72 & $0.83(32)$ \\
\hline $\begin{array}{l}\text { Ability to motivate and } \\
\text { direct interviewee in a self- } \\
\text { regulating and dominant } \\
\text { fashion }\end{array}$ & 4.3 & 0.66 & 3.85 & 0.69 & $0.80(33)$ \\
\hline $\begin{array}{l}\text { Ethical ability to keep } \\
\text { interviewee information and } \\
\text { trusted matters etc. } \\
\text { confidential as a counselor }\end{array}$ & 4.55 & 0.67 & 4.24 & 0.63 & $0.79(34)$ \\
\hline $\begin{array}{l}\text { Sense of affection for the } \\
\text { interviewee and general } \\
\text { respect for people }\end{array}$ & 4.43 & 0.73 & 4.15 & 0.76 & $0.74(35)$ \\
\hline $\begin{array}{l}\text { Ability to accommodate and } \\
\text { adequately sympathize with/ } \\
\text { accept interviewee without } \\
\text { criticism }\end{array}$ & 4.34 & 0.73 & 3.98 & 0.71 & $0.71(36)$ \\
\hline $\begin{array}{l}\text { Flexibility to calmly cope } \\
\text { with interviewee whilst } \\
\text { retaining an unbiased and } \\
\text { open attitude }\end{array}$ & 4.24 & 0.7 & 3.98 & 0.73 & $0.66(37)$ \\
\hline $\begin{array}{l}\text { Sense of responsibility and } \\
\text { honesty enabling continual } \\
\text { transformation of } \\
\text { interviewee }\end{array}$ & 4.28 & 0.66 & 4.03 & 0.76 & $0.64(38)$ \\
\hline $\begin{array}{l}\text { Ability to retain a calm head } \\
\text { in coping with various } \\
\text { different situations }\end{array}$ & 4.22 & 0.71 & 3.96 & 0.73 & $0.62(39)$ \\
\hline $\begin{array}{l}\text { Sympathizing attitude } \\
\text { enabling support and belief } \\
\text { in interviewee }\end{array}$ & 4.31 & 0.72 & 4.03 & 0.72 & $0.61(40)$ \\
\hline $\begin{array}{l}\text { Ability to operate existing } \\
\text { career counseling programs } \\
\text { (CAP/ CDP, etc.) }\end{array}$ & 3.98 & 0.89 & 3.24 & 1.1 & $0.58(41)$ \\
\hline $\begin{array}{l}\text { Ability to develop career } \\
\text { guidance programs }\end{array}$ & 3.76 & 1.02 & 2.9 & 1.07 & $0.50(42)$ \\
\hline $\begin{array}{l}\text { Ability to persuasively } \\
\text { lecture in a manner } \\
\text { appropriate to interviewee's } \\
\text { characteristics }\end{array}$ & 4.01 & 0.97 & 3.36 & 1.05 & $0.45(43)$ \\
\hline $\begin{array}{l}\text { Ability to interpret and } \\
\text { implement psychological } \\
\text { evaluations relating to career } \\
\text { counseling }\end{array}$ & 4.13 & 0.85 & 3.55 & 0.87 & $0.41(44)$ \\
\hline $\begin{array}{l}\text { Ability to amend documents } \\
\text { relating to job applications } \\
\text { and interviews }\end{array}$ & 4.32 & 0.73 & 3.95 & 0.79 & $0.36(45)$ \\
\hline $\begin{array}{l}\text { Ability to utilize computers } \\
\text { equipped with lecture } \\
\text { materials (PPT, Video } \\
\text { software, etc.) }\end{array}$ & 3.94 & 0.84 & 3.6 & 0.89 & $0.30(46)$ \\
\hline
\end{tabular}




\begin{tabular}{llllll}
\hline $\begin{array}{l}\text { Knowledge of theory } \\
\text { currently utilized in the } \\
\text { counseling field }\end{array}$ & 3.83 & 0.77 & 3.38 & 0.75 & $0.28(47)$ \\
\hline $\begin{array}{l}\text { Knowledge relating to } \\
\text { psychological theory for the } \\
\text { understanding of human } \\
\text { behavior, personality, } \\
\text { stimulus, and motivation etc. }\end{array}$ & 3.84 & 0.75 & 3.32 & 0.81 & $0.25(48)$ \\
\hline $\begin{array}{l}\text { Knowledge relating to the } \\
\text { developmental theories of } \\
\text { vocation and counseling }\end{array}$ & 3.74 & 0.79 & 3.26 & 0.78 & $0.20(49)$ \\
\hline $\begin{array}{l}\text { Ability to discover job- } \\
\text { seeking companies }\end{array}$ & 4.26 & 0.87 & 3.74 & 1.01 & $0.20(50)$ \\
\hline $\begin{array}{l}\text { Ability to find employment } \\
\text { for job seekers }\end{array}$ & 4.45 & 0.71 & 4.04 & 0.78 & $0.15(51)$ \\
\hline $\begin{array}{l}\text { Ability to operate and plan } \\
\text { events relating to the fields } \\
\text { of 'career' and 'vocation' }\end{array}$ & 3.85 & 0.86 & 3.34 & 1.02 & $0.11(52)$ \\
\hline $\begin{array}{l}\text { Ability to offer adaptive } \\
\text { support after employment }\end{array}$ & 3.77 & 0.85 & 3.27 & 0.88 & $0.07(53)$ \\
\hline
\end{tabular}

\section{Discussion and Conclusion}

This study aims to present implications through deductions made from looking at the importance and performance recognition values of necessary competencies (in accordance with the kind of jobnot individual characteristics). These take the form of primary materials which aid the development of talent, competency, and essential values demanded of career and vocational counselors by schools, employment centers, job centers, and private enterprises etc..

First, the total average results analysis value was 4.13 (maximum 5.00, minimum 1.8) with a standard deviation of 0.817 , showing the gap between vocational counselor competency importance and performance. The total average competency analysis result for performance was 3.64 (maximum 5.00, minimum 1.22), and had a standard deviation of 0.850 . Through this it can be observed that, in each area, values for performance competency are comparatively lower than importance.

Second, in order to analyze areas showing a meaningful difference between importance and performance in the 7 capability areas for vocational counselors, a paired t-test was implemented on values displaying a significance level of .05: the results show meaningful difference in all 7 areas. Although this does not imply that there were high importance values for each separate job group, it does imply that there was high variation in performance. It follows that conditions should be established that stimulate competency in accordance with each applicable job group.

Third, in the analyzed significant difference results of the sub-categories of importance and performance competencies, it was evident that all 53 sub- competencies of the 7 areas displayed a significant difference level of .05. Especially in the 5 competency areas showing large differences in importance and performance, there is a basis for the judgment that an educational process for vocational counselors should be established, and that the development of suitable educational content in this area could be necessary to heighten performance levels.

Fourth, utilizing IPA analysis, the competency areas and sub-categories demanded of vocational counselors were examined. Of the 7 areas initially examined, the following 3 displayed high importance but low performance values: Counseling program development and operation, Job-seeking support ability, and Job and career information management ability.

Fifth, through an examination of Borich requirement analysis, there was the greatest points difference evident in the following 5 competency of (improvement) requirements : Knowledge relating to the type and job information of various careers, Knowledge related to future social change, Knowledge relating to the business recruitment process and personnel system, Understanding of life organization, Ability to search for job information . Through this it can be observed that background knowledge for various careers and ability for radical social change are more important than knowledge relating to the developmental theories of vocation and counseling.

In future studies, foundational materials could form the basis for the planning, development, and evaluation standard of effective competency development programs when designing educational processes based on the results of existing studies. 
Ability to operate and plan events relating to the fields of 'career' and 'vocation', Ability to find employment for job seekers, Ability to find employment for job seekers, Ability to discover jobseeking companies, Knowledge relating to the developmental theories of vocation and counseling.

\section{Reference}

[1] Borich, G. D. (1980). A needs assessment model for conducting follow-up studies. Journal of Teacher Education, 31(3), 39-42.

[2] Cedefop, (2009). Professionalising career guidance: Practitioner Competences and Qualification Routes in Europe.

[3] Choi, E. (2012). A survey awareness on instructional competencies of cyber education for elementary and middle school using an importanceperformance analysis (IPA). CNU Journal of Educational Studies, 33(1), 187-210.

[4] Dubois, D. D. (1993). Competency-Based Performance Improvement: A Strategy for Organizational Change. HRD Press, Inc., 22 Amherst Road, Amherst, MA 01002.

[5] Gebelein, S. H.(1996), Employee Development: Multi-rather feedback goes strategic, HR Focus, 73(1), 87-98.

[6] IAEVG. (2003). International competencies for educational and vocational guidance practitioners.

[7] Jo, M. (2006). The importance and performance analysis of service encounter quality by types of restaurants. . Journal of the Korean Society of Food Science and Nutrition, 35(8), 1076-1087.

[8] Jo, S. \& Jo, H. (2012). Case study of the competency modeling of internet information security company. Journal of human resource management research, 19(4), 53-74.

[9] Kim, B., Jeong, C., Kim, B. (2001). Career counseling. Hakjisa.

[10] Kim, H. (2014). Analysis of outplacement counselor's competency. Department of education, the graduate school, Sookmyung Women's University.

[11] Kim, K. (1995). Counseling psychology. Hakjisa.

[12] Kim, K., Lee, G. (2013). The identification of competencies and indicators needed for employment service practitioners. The Journal of Vocational Education Research, 32(3), 1-24.

[13] Kim, S. (2010). Analysis of career and vocational counselor's competence. Department of career counseling, the graduate school of education, Kwangwoon University.

[14] Kim, S., Tak, J. (2011). Development of career and vocational counselor's competences scale and validation. Korean Journal of Psychology: General/, 30(2), 461-481.

[15] Ko, H., Oh, Y., Lee, S. (2011). The competence of private employment service staff and measures to strengthen their capabilities. Korea Research Institute of Vocation Education \& Training.

[16] Kong, J (2006). Job analysis in field of vocational counseling. Human Resources Development Service of Korea.

[17] Korea Research Institute of Vocation Education \& Training. (1998). Job Analysis of Vocational Counselor.

[18] Lee, J. (2007). The exploration of educational needs for vocational counselors, who are working for elder clients. The Korea Journal of Counseling, 8(3), 1011-1029.

[19] Martilla, J. A., \& James, J. C. (1977). Importance-performance analysis. The Journal of Marketing, 77-79

[20] McClelland, D. C. (1973). Testing for competence rather than for Intelligence. American Psychologist, Jan. 1-14.

[21] Mullins, G. W., \& Spetich, B. L. S. (1987). Importance-performance analysis. Visitor Behavior, 2(3), 3.

[22] National Steering Committee. (2001). Canadian standards and guideline for career development: Snapshot. http://www.hrsdc.gc.ca.

[23] Park, H. (2015). Analysis of competency and training needs of private employment agency vocational counselors. Department of vocation, the graduate school of public administration, Kyonggi University.

[24] Parsons, F. (1909). Choosing a vocation. Houghton Mifflin.Human Resources Development Service of Korea. (2013). National Competency Standards \& Usage Package: Vocational Counseling.

[25] Roh K. \& Choi, Y. (2013). Job analysis on 
career planners in the reemployment support center for career interrupted women through DACUM process. The Korean Journal of Human Resource Development Quarterly, 15(3), 161-187.

[26] Spencer, L.M., Spencer, S.M., (1993). Competence at work: Models for superior performance.

[27] Yoon, H. (2009). The developmental process and factors influencing the expertise of PES (public employment services) vocational counselors in Korea. Department of education graduate school, Hongik University.

[28] Homepage of Ministry of Employment and Labor. http://www.moel.go.kr

[29] Homepage of Korea Research Institute of Vocation Education \& Training. http://www.pqi.or.kr

[30] Homepage of Korea Research Institute of Vocation Education \& Training. http://q-net.or.kr 